\title{
Permeability variation in crystalline rocks due to low-grade solution phenomena
}

\author{
Rüdiger Kilian and Michael Stipp \\ Institut für Geowissenschaften und Geographie, Martin-Luther-Universität Halle-Wittenberg, \\ 06120 Halle an der Saale, Germany \\ Correspondence: Rüdiger Kilian (ruediger.kilian@geo.uni-halle.de) \\ Published: 10 November 2021
}

\begin{abstract}
Permeability of crystalline rocks depends on parameters such as density and interconnectivity of fractures and pores. While in pristine crystalline rocks porosity is usually considered to be low, low-grade solution phenomena such as the formation of episyenites occur occasionally and may cause a local dramatic increase in porosity and permeability. These solution phenomena can be effective in otherwise unaltered rocks and may result in the preferential removal of certain mineral phases, especially of quartz so that porosities correspond to the spatial distribution of the previously existing mineral phase if no subsequent mineralization occurs (e.g., Pennacchioni et al., 2016). Using light-optical and scanning electron microscopy, X-ray tomography, micro-XRD, as well as digital image analysis, the differences in connectivity and hence permeability between, for example, quartz-depleted granite, gneiss, and schist can be characterized and quantified.

We demonstrate that such porosities do not necessarily result in high permeabilities in an undeformed granodiorite from the Central Gneiss unit of the Tauern Window (Lago di Neves area, Italy), since former quartz aggregates are not interconnected due to their relatively late crystallization age and the preservation of the magmatic fabric; however, in the case of moderate mylonitic deformation, quartz as rheologically weak phase forms interconnected aggregates and layers. Its dissolution results in an extremely increased permeability. Therefore, not only the content and grain size but also the distribution, shape and alignment of minerals are crucial for rock permeability and need to be carefully investigated when searching for a final repository of highly radioactive waste in crystalline rocks. Especially since local shear zones may form in otherwise undeformed intrusive bodies, a detailed structural analysis beyond the exclusion of the presence of fractures is required to mitigate the risk of a long-lasting nuclear waste disposal.
\end{abstract}

Kurzfassung. Die Permeabilität kristalliner Gesteine hängt von Parametern ab, wie etwa der Dichte und der Interkonnektivität von Brüchen und Poren. Während die Porosität in wenig alteriertem Kristallingestein in der Regel als minimal angesehen wird, können Lösungsprozesse, wie diese, die zur Bildung von Episyenit führen, einen lokalen, dramatischen Anstieg von Porosität und Permeabilität verursachen. Diese Lösungserscheinungen können zu einer präferenziellen Herauslösung bestimmter Mineralphasen führen, wobei die räumliche Verteilung der Porosität der Verteilung der gelösten Mineralphasen entspricht, sofern keine nachfolgende Mineralisierung eintritt (z. B. Pennacchioni et al., 2016). Mithilfe von Licht- und Rasterelektronenmikroskopie, Röntgentomographie, Mikro-XRD sowie digitaler Bildanalyse lassen sich die Unterschiede in der Konnektivität - und damit in der Permeabilität - zwischen, beispielsweise, quarzarmen Graniten, Gneisen und Schiefern charakterisieren und quantifizieren.

Wir zeigen dass eine solche Porosität in einem undeformierten Granodiorit aus dem Zentralgneis des Tauernfensters im Gebiet des Neves-Stausees (Italien) nicht unbedingt in einer hohen Permeabilität resultiert, da ehemalige Quarzaggregate aufgrund ihres relativ späten Kristallisationsalters und der Erhaltung des magmatischen Gefüges nicht miteinander verbunden sind. Bei einer mäßig ausgeprägten mylonitischen Verformung bildet Quarz als rheologisch schwache Phase jedoch miteinander verbundene Aggregate und Lagen. Seine Lösung führt zu einer deutlich erhöhten Permeabilität. Daher sind nicht nur der Gehalt und die Korngröße der Mineralphasen, sondern auch ihre Verteilung, Form und Ausrichtung entscheidend für die Permeabilität des alterierten 
Gesteins. Diese Gefügeeigenschaften sollten bei der Erkundung eines Endlagers für hochradioaktive Abfälle in kristallinen Gesteinen sorgfältig untersucht werden. Da lokale Scherzonen in sonst undeformierten Intrusivkörpern häufig vorkommen, ist eine detaillierte Strukturanalyse, die über den Ausschluss von spröden Bruchzonen hinausgeht, erforderlich, um das Risiko einer langfristigen Lagerung radioaktiver Abfälle zu minimieren.

\section{References}

Pennacchioni, G., Ceccato, A., Fioretti, A. M., Mazzoli, C., Zorzi, F., and Ferretti, P.: Episyenites in meta-granitoids of the Tauern Window (Eastern Alps): unpredictable?, J. Geodyn., 101, 73-87, https://doi.org/10.1016/j.jog.2016.04.001, 2016. 